\title{
Between-year variation in seed weights across altitudes in the high-alpine plant Eritrichium nanum
}

\author{
Lea R. Wirth · René Graf · Felix Gugerli • \\ Urs Landergott $\cdot$ Rolf Holderegger
}

Received: 6 May 2009/Accepted: 9 September 2009/Published online: 16 September 2009

(C) Springer Science+Business Media B.V. 2009

\begin{abstract}
Seed weight is a prominent life history trait of plants affecting dispersal, establishment, and survival. In alpine environments, the few studies investigating the effect of elevation on seed weight within species have mainly detected a decrease in seed weight with increasing elevation. This relationship is generally attributed to the adverse climate at high elevations. In order to test this hypothesis, we analyzed seed weight variation across altitudes $(2,435-3,055 \mathrm{~m}$ a.s.l.) in two consecutive years that differed in weather conditions in the high-alpine cushion plant Eritrichium nanum. We found a significant reduction in seed weight with increasing elevation in both years, but in the growing season with more adverse weather conditions, the reduction was more substantial than in the more favorable year. We conclude that alpine plants may be able to produce well-developed seeds at low elevations in almost all years, independent of weather conditions, whereas reproduction through seeds is potentially limited to years of favorable weather at high elevation.
\end{abstract}

Keywords Seed mass - Seed size · Elevation $\cdot$ Weather variation $\cdot$ Alps

L. R. Wirth $(\bowtie) \cdot$ R. Graf · F. Gugerli ·

U. Landergott $\cdot$ R. Holderegger

WSL Swiss Federal Research Institute,

Zürcherstrasse 111, CH - 8903 Birmensdorf, Switzerland

e-mail: lea.wirth@wsl.ch

\section{Introduction}

When comparing lowland with alpine plant species, an obvious adaptation to the adverse alpine environment is the reduced size of alpine plants (Jenny-Lips 1948; Körner 2003). In contrast, it has been observed that seed weight or seed size is often increased in alpine species as compared with taxonomically related lowland species (Blionis and Vokou 2005; Pluess et al. 2005; but see Baker 1972). Seed size is of special interest, because it is a prominent life history trait of plants that affects dispersal, establishment, and seedling survival (Leishman et al. 2000). Multiple comparisons of species pairs from the Swiss Alps showed heavier seeds in alpine than in lowland species (Landolt 1967; Pluess et al. 2005). The same relationship was observed along an altitudinal gradient at Mt. Olympos in Greece (Blionis and Vokou 2002, 2005). A possible explanation for these findings is that embryos from heavier seeds are better provisioned than those from lighter seeds. Under the increasingly adverse ecological conditions along altitudinal gradients, such as shorter growing seasons and lower mean temperatures (Landolt 1967; Körner 2003), seedlings from heavy seeds might be more successful in establishing and surviving (Leishman et al. 2000; Moles and Westoby 2004) This fitness advantage of heavy seeds could have led to the evolution of heavy-seeded species at high elevations.

In contrast to the above mentioned species-pair comparisons, the few studies investigating variation 
in seed weight within single alpine species have mostly reported a reduction in seed weight with increasing elevation. For instance, Eritrichium nanum, Saxifraga oppositifolia, Scabiosa lucida, and Ranunculus acris produced lighter seeds with increasing elevation, while Epilobium fleischeri showed no directional change in seed weight (Totland and Birks 1996; Totland 1997a; Pluess et al. 2005; Zoller et al. 2005). These results have been attributed to low temperatures and short growing seasons at high elevations, the two most important factors affecting seed maturation and, thus, seed weight (Totland and Birks 1996; Totland 1997a, b; Wagner and Reichegger 1997; Baskin and Baskin 1998; Blionis and Vokou 2005).

If seed weight of alpine plants is mostly influenced by environmental constraints, we should not only find decreasing seed weight with increasing elevation, but also find variation in seed weights owing to annual variation in weather conditions. Annual variation in seed germinability and seed production has been found in long-term investigations of alpine and arctic plant species (Laine et al. 1995; Zoller et al. 2005). To our knowledge, however, no investigation has addressed seed weight variation in a high-alpine plant species along an altitudinal range, and in seasons with different weather conditions.

Here, we report on variation in seed weight across altitudes from 2,435 to $3,055 \mathrm{~m}$ a.s.l. in the highalpine cushion plant E. nanum in two consecutive, but climatically different growing seasons in the Swiss Alps. We addressed the following two questions: (1) Does seed weight in E. nanum decrease with increasing altitude? (2) Is annual climatic variation affecting seed weight across altitudes?

\section{Materials and methods}

Eritrichium nanum (L.) Gaud. (Boraginaceae) is a showy, blue-flowered alpine cushion plant. This perennial multi-flowered herb grows in high-alpine habitats of Central Europe, mostly between 2,500 and 3,000 $\mathrm{m}$ a.s.l. (Schröter, 1926). The flowering season starts in June at low elevations and continues until the end of July at high elevations. Flowers are pollinated by various generalist insects, mostly Diptera (Zoller et al. 2002). Zoller et al. (2002) reported the flowers to be self-compatible, but predominantly outcrossed.
Fruits contain four nutlets, each with a single seed (Gams 1975).

We selected 15 study sites at different elevations in the Upper Engadine and adjacent valleys of southeastern Switzerland (Table 1). The sites were situated between 2,435 and 3,055 $\mathrm{m}$ a.s.l. and separated from one another by at least $1 \mathrm{~km}$. All the sites consisted of large, preferably flat scree areas with naturally sparse vegetation on windswept crests, where vegetation becomes snow-free early in the season.

All the 15 sites were sampled twice, once in 2005 and once in 2006. The growing seasons in these 2 years differed in their weather, especially in July (Table 2), the main period of seed maturation. July 2005 was cold and partly snowy, whereas July 2006 was substantially warmer. In contrast, the weather in spring and late summer was more favorable in 2005 than in 2006.

From July to August, fully developed ripe seeds from 10 randomly selected cushions were sampled per site, just before they would have been dispersed (Table 1). After drying at room temperature, seeds were stored at $2^{\circ} \mathrm{C}$ for five months. Ten filled seeds (i.e., nutlets without coat) were randomly chosen per cushion and weighed on an electronic analytical

Table 1 Characteristics, locations, and sampling dates in 2005 and 2006 for 15 E. nanum sites in southeastern Switzerland, where seeds were collected

\begin{tabular}{lllll}
\hline Site & $\begin{array}{l}\text { Elevation } \\
\text { (m a.s.1. })\end{array}$ & $\begin{array}{l}\text { Longitude/latitude } \\
(\text { E/N) }\end{array}$ & \multicolumn{2}{l}{ Sampling date } \\
\cline { 4 - 5 } & & & 2005 & 2006 \\
\hline 1 & 2,435 & $10^{\circ} 02^{\prime} 38^{\prime \prime} / 46^{\circ} 23^{\prime} 56^{\prime \prime}$ & $12 / 08$ & $25 / 07$ \\
2 & 2,460 & $9^{\circ} 39^{\prime} 17^{\prime \prime} / 46^{\circ} 25^{\prime} 20^{\prime \prime}$ & $13 / 08$ & $27 / 07$ \\
3 & 2,600 & $9^{\circ} 47^{\prime} 20^{\prime \prime} / 46^{\circ} 24^{\prime} 57^{\prime \prime}$ & $16 / 08$ & $29 / 07$ \\
4 & 2,655 & $9^{\circ} 39^{\prime} 53^{\prime \prime} / 46^{\circ} 24^{\prime} 56^{\prime \prime}$ & $18 / 08$ & $27 / 07$ \\
5 & 2,700 & $9^{\circ} 47^{\prime} 33^{\prime \prime} / 46^{\circ} 24^{\prime} 41^{\prime \prime}$ & $16 / 08$ & $29 / 07$ \\
6 & 2,735 & $9^{\circ} 36^{\prime} 45^{\prime \prime} / 46^{\circ} 25^{\prime} 23^{\prime \prime}$ & $24 / 08$ & $27 / 07$ \\
7 & 2,790 & $9^{\circ} 44^{\prime} 26^{\prime \prime} / 46^{\circ} 25^{\prime} 20^{\prime \prime}$ & $24 / 08$ & $27 / 07$ \\
8 & 2,820 & $9^{\circ} 44^{\prime} 10^{\prime \prime} / 46^{\circ} 29^{\prime} 40^{\prime \prime}$ & $27 / 08$ & $30 / 07$ \\
9 & 2,840 & $9^{\circ} 35^{\prime} 15^{\prime \prime} / 46^{\circ} 27^{\prime} 55^{\prime \prime}$ & $25 / 08$ & $31 / 07$ \\
10 & 2,875 & $9^{\circ} 44^{\prime} 56^{\prime \prime} / 46^{\circ} 30^{\prime} 90^{\prime \prime}$ & $27 / 08$ & $09 / 08$ \\
11 & 2,905 & $9^{\circ} 44^{\prime} 57^{\prime \prime} / 46^{\circ} 29^{\prime} 59^{\prime \prime}$ & $27 / 08$ & $09 / 08$ \\
12 & 2,925 & $9^{\circ} 46^{\prime} 38^{\prime \prime} / 46^{\circ} 30^{\prime} 19^{\prime \prime}$ & $29 / 08$ & $14 / 08$ \\
13 & 2,960 & $9^{\circ} 42^{\prime} 17^{\prime \prime} / 46^{\circ} 30^{\prime} 18^{\prime \prime}$ & $27 / 08$ & $09 / 08$ \\
14 & 3,020 & $9^{\circ} 43^{\prime} 90^{\prime \prime} / 46^{\circ} 30^{\prime} 14^{\prime \prime}$ & $27 / 08$ & $09 / 08$ \\
15 & 3,055 & $9^{\circ} 47^{\prime} 79^{\prime \prime} / 46^{\circ} 30^{\prime} 50^{\prime \prime}$ & $29 / 08$ & $14 / 08$ \\
\hline
\end{tabular}


Table 2 Weather conditions (thawing degree days i.e., sum of degrees over $0{ }^{\circ} \mathrm{C}$ per day, mean temperature, and days with snowfall in July and August) during the growing seasons of E. nanum of 2005 and 2006

\begin{tabular}{|c|c|c|c|c|c|c|}
\hline & \multicolumn{2}{|c|}{ Thawing degree days ${ }^{\mathrm{a}}$} & \multicolumn{2}{|c|}{ Mean temperature $\left({ }^{\circ} \mathrm{C}\right)^{\mathrm{a}}$} & \multicolumn{2}{|c|}{ Number of days with snowfall ${ }^{\mathrm{b}}$} \\
\hline & 2005 & 2006 & 2005 & 2006 & 2005 & 2006 \\
\hline May & 21.9 & 2 & -3.1 & -3.6 & - & - \\
\hline June & 73.5 & 77.9 & 1 & 0.3 & - & - \\
\hline July & 79.1 & 154.5 & 2 & 5 & 7 & 0 \\
\hline August & 36.8 & 13.8 & 0.3 & -1.4 & 7 & 6 \\
\hline
\end{tabular}

${ }^{a}$ Data from MeteoSwiss station Piz Corvatsch (3,315 m a.s.1; Engadine, Switzerland)

b Personal observations at study sites

balance (Mettler Toledo MX5, Greifensee). We then calculated mean seed weight per site per year, as well as the standard errors.

The effect of elevation on mean seed weight was tested using ordinary least squares (OLS) regressions with permutation testing $(N=10,000)$ implemented in the software BLOSSOM (Cade and Richards 2005). By analyzing two single regressions (separately for each year), we explored the effect of elevation on mean seed weight. In order to assess whether the effect of elevation differed between the two study years, we investigated the difference in slope of the above regressions by testing for a year $\times$ elevation interaction.

\section{Results and discussion}

Average seed weight in E. nanum was $0.327 \mathrm{mg}$, with a wide range from $0.092 \mathrm{mg}$ to $0.854 \mathrm{mg}$. In both years, seed weight significantly decreased with increasing elevation (2005: $P=0.001, R^{2}=0.573$; 2006: $P=0.023, R^{2}=0.340$; Fig. 1 ). However, the slopes of the two regression lines were significantly different, i.e., the effect of elevation was more pronounced in 2005 than in $2006(P=0.045$; Fig. 1). Seeds from the lowest site $(2,435 \mathrm{~m}$ a.s.l.) were four times heavier than seeds from the highest site $(3,055 \mathrm{~m}$ a.s.1.) in 2005, whereas this difference was only twofold in 2006. In some of the populations at middle elevations, no difference in seed weight was detected between years.

Mean seed weight of E. nanum generally decreased with increasing elevation along an altitudinal gradient of $620 \mathrm{~m}$, representing most of the altitudinal range of the species. Our findings are in accordance with most

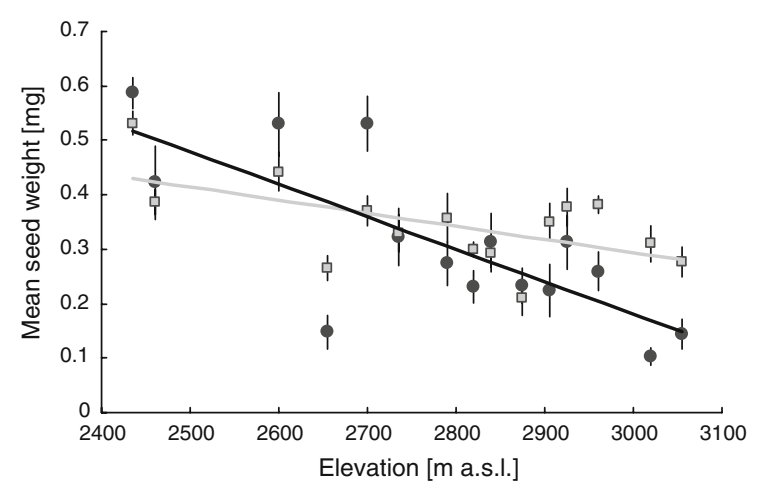

Fig. 1 Relationship between seed weight in E. nanum (mean per site and year \pm S.E.) and elevation. Black circles and black line indicate values and linear regression $(y=-0.0002 x+1.0174)$, respectively, for 2005, and grey squares and grey line indicate those for $2006(y=-0.0006 x+1.9701)$

of the other studies assessing the relationship between seed weight and elevation in single alpine plant species. Zoller et al. (2005) investigated seed weight of E. nanum populations along an altitudinal gradient of $300 \mathrm{~m}$. They found about half of the reduction we observed (i.e., mean over both years). Similarly, an investigation on S. oppositifolia and S. lucida across an altitudinal gradient of $1,000 \mathrm{~m}$ showed a half reduction in seed weight (Pluess et al. 2005). However, seed weight data from different years were pooled in these two studies. Totland (1997a) and Totland and Birks (1996) found a more than one and a half time reduction in seed weight in a one-year study on $R$. acris along a 300-m increase in elevation. Frequently changing weather conditions, low temperatures, and short growing seasons, i.e., unfavorable conditions for seed maturation at high elevations, have been proposed to cause the observed decrease in seed weight with increasing elevation (Galen 1985; 
Corbet 1990; Totland and Birks 1996; Totland 1997b; Wagner and Reichegger 1997; Pluess et al. 2005).

It has been hypothesized that seed development in alpine plants is substantially or even mostly influenced by climatic factors (Billings and Mooney 1968). Especially, histogenesis (i.e., formation of cell number and tissue volume) appears to be more sensitive to temperature than seed filling and maturation (Wagner and Reichegger 1997). Our findings support this statement. Seed weight in E. nanum declined significantly with altitude and, thus, with increasing climatically adverse conditions in both study years, and the effect of elevation on seed weight was much more pronounced in 2005 , i.e., the climatically less favorable year. A fourfold difference in mean seed weight across altitudes was found in 2005 as compared with a less-pronounced difference in 2006, the more favorable year. Nevertheless, seeds at low altitudinal sites were heavier in 2005 than in 2006. This was most likely caused by an interplay among weather conditions and phenology in E. nanum. Weather conditions in spring, when histogenesis at low study sites took place, were more favorable in 2005 than in 2006 (Table 2). It is reasonable to assume that plants at low altitudinal sites could profit from good spring weather in 2005, but less so in 2006.

Other studies investigating seed weight of alpine plants in climatically contrasting environments showed that seed maturation in alpine plants is highly temperature dependent (Totland 1997b; Wagner and Reichegger 1997). While comparing plants of Leontodon autumnalis var. taraxaci growing in opentop chambers (OTCs), experiencing a $2.3^{\circ} \mathrm{C}$ increase in air temperature, with those in control plots, Totland (1997b) found heavier seeds in OTCs than in control plots. Similarly, the alpine sedge Carex firma produced heavier seeds at sunny sites than at north-facing sites (Wagner and Reichegger 1997). In our study, the particularly low seed weight at the site at $2,655 \mathrm{~m}$ a.s.l. (Fig. 1) may also indicate this exposure effect, as this site had the most northern exposure of all our study sites.

During the warm and favorable July of 2006, E. nanum plants at the highest elevations produced seeds with a similar weight as the plants from sites at middle elevations. This resulted in a much weaker relationship between seed weight and elevation in 2006. During a favorable alpine summer, high-alpine plants were thus able to produce heavy seeds (Billings and Mooney 1968). For perennial alpine plant species such as E. nanum, successful sexual reproduction through seed may be limited to years of favorable summer weather at high elevations, if successful establishment of seedlings depends on seed weight (Leishman et al. 2000; Moles and Westoby 2004). In contrast, seed weight of alpine plants growing at lower elevations may be less affected by weather conditions. Seen over the whole life time of a perennial alpine plant, even episodic seed production may be sufficient for population maintenance in high-alpine habitats. Our study suggests that conducting studies across multiple years is important for uncovering such variation in effective reproductive success.

Acknowledgments We are indebted to Andrea Lübberstedt, Erika Gadola, Nike Kräutler, Reto Buser, Simon Weber, Silke Werth, and Sonia Angelone for their help during collection of seeds, often under adverse weather conditions. Many thanks are due to Urs Kamm, Dominique Bühler, Nick Waser, and Andreas Erhardt, and two anonymous referees for their respective comments on the manuscript. Weather data were provided by MeteoSwiss, Federal Office of Meteorology and Climatology. This study was financially supported by the Swiss National Science Foundation (3100A0-107962).

\section{References}

Baker HG (1972) Seed weight in relation to environmental conditions in California. Ecology 53:997-1010

Baskin CC, Baskin JM (1998) Seeds. Academic Press, San Diego

Billings WD, Mooney HA (1968) The ecology of arctic and alpine plants. Biol Rev 43:481-529

Blionis GJ, Vokou D (2002) Structural and functional divergence of Campanula spatulata subspecies on Mt Olympos (Greece). Plant Syst Evol 232:89-105

Blionis GJ, Vokou D (2005) Reproductive attributes of Campanula populations from Mt Olympos, Greece. Plant Ecol 178:77-88. doi:10.1007/s11258-004-2495-6

Cade BS, Richards JD (2005) User manual for BLOSSOM statistic software. U.S. Geological Survey, Fort Collins

Corbet SA (1990) Pollination and the weather. Israel J Bot 39: $13-30$

Galen C (1985) Regulation of seed-set in Polemonium viscosum-floral scents, pollination, and resources. Ecology 66:792-797

Gams H (1975) Boraginaceae. In: Berger H (ed) Gustav Hegi, Illustrierte Flora von Mitteleuropa 5(3). Parey, Berlin, pp 2122-2233

Jenny-Lips H (1948) Vegetation der Schweizer Alpen. Gutenberg, Zürich

Körner C (2003) Alpine plant life. Springer, Berlin

Laine K, Malila E, Siuruainen M (1995) How is annual climatic variation reflected in the production of germinable 
seeds of arctic and alpine plants in the northern Scandes? European Commission, Brüssel, pp 89-95

Landolt E (1967) Gebirgs- und Tieflandsippen von Blütenpflanzen in Bereich der Schweizer Alpen. Bot Jahrb Syst Pflanzengesch Pflanzengeogr 86:463-480

Leishman M, Writh IJ, Moles AT, Westoby M (2000) The evolutionary ecology of seed size. In: Fenner M (ed) Seeds. CABI, New York, pp 31-57

Moles AT, Westoby M (2004) Seedling survival and seed size: a synthesis of the literature. J Ecol 92:372-383

Pluess AR, Schutz W, Stöcklin J (2005) Seed weight increases with altitude in the Swiss Alps between related species but not among populations of individual species. Oecologia 144:55-61. doi:10.1007/s00442-005-0047-y

Schröter C (1926) Das Pflanzenleben der Alpen. Raustein, Zürich

Totland Ø (1997a) Limitations on reproduction in alpine Ranunculus acris. Can J Bot 75:137-144
Totland Ø (1997b) Effects of flowering time and temperature on growth and reproduction in Leontodon autumnalis var. taraxaci, a late-flowering alpine plant. Arct Antarct Alp Res 29:285-290

Totland Ø, Birks HJB (1996) Factors influencing inter-population variation in Ranunculus acris seed production in an alpine area of southwestern Norway. Ecography 19:269-278

Wagner J, Reichegger B (1997) Phenology and seed development of the alpine sedges Carex curvula and Carex firma in response to contrasting topoclimates. Arct Antarct Alp Res 29:291-299

Zoller H, Lenzin H, Erhardt A (2002) Pollination and breeding system of Eritrichium nanum (Boraginaceae). Plant Syst Evol 233:1-14

Zoller H, Lenzin H, Rusterholz HP, Stöcklin J (2005) Increasing population density and seed production with altitude in Eritrichium nanum (Boraginaceae)—an arctic alpine obligatory seeder. Arct Antarct Alp Res 37:41-48 